\title{
Variability of Young Maize Plants Traits in a Set of Local Populations
}

\author{
Leon MUNTEAN ${ }^{1 *}$, Cornelia STAN² ${ }^{2}$ Nicolae TRITEAN ${ }^{3}$, Ioan HAS $^{1,3}$, Voichita HAS $^{3}$, \\ 1) Faculty of Agriculture, University of Agricultural Sciences and Veterinary Medicine Cluj-Napoca, \\ 3-5 Manastur St., 400372 Cluj-Napoca, Romania; \\ 2) Territorial Inspectorate for Seeds and Planting material Quality Cluj, 121 Fabricii de Zahar Street, \\ 400624 Cluj-Napoca, Romania \\ 3) Agricultural Research-Development Station Turda, 27 Agriculturii Street, 401100 Turda, Romania \\ * corresponding author: leon.muntean@usamvcluj.ro
}

Bulletin USAMV series Agriculture 71(2)/2014

Print ISSN 1843-5246; Electronic ISSN 1843-5386

DOI: $10.15835 /$ buasvm-agr: 10839

\begin{abstract}
Taking into account the importance of root and coleoptile and mesocotyl length of maize young plants, we considered appropriate to analyse the variability of these traits in a set of maize local populations. The root system development, the mesocotyl and the coleoptile were studied in a number of 41 local populations at The Maize Breeding Department of ARDS Turda. The average length was $28.42 \mathrm{~cm}$ for embrionary roots, $17.37 \mathrm{~cm}$ for primary roots, $1.43 \mathrm{~cm}$ for mesocotyl, $3.50 \mathrm{~cm}$ for coleoptile and 4.92 for plantlets. The variability was low for embrionary roots, coleoptile and plantlets length and medium for primary roots and mesocotyl length. A correlation was noticed between the length of mesocotyl and the length of coleoptile and plantlets. The size of roots, mesocotyl and coleoptile is influenced by the area where the local population is formed. Local populations with high root and coleoptile length such as Tulca, Lapusneac and Biertan can be used for obtaining some valuable inbred lines of maize.
\end{abstract}

Keywords: coleoptile, local populations, maize, mesocotyl, roots, variability

\section{INTRODUCTION}

Germination is the renewal of enzymatic activity that results in cell division and elongation and, ultimately, embryo emergence through the seed coat. Germination is triggered by absorption of water through the seed coat (Nielsen, 2010c). Successful germination (fast \& uniform) does not guarantee alone the stand establishment in corn. The next crucial phase is the establishment of a vigorous nodal root system. The maize roots are originated from the scutelar node located in the seed embryo and are composed of the primary and seminal roots (Nielsen, 2010a).

The primary root emerges first, near the tip end of the kernel, within two to three days in warm soils with adequate moisture or much longer if soil temperatures hover at or below 10C . In cooler or drier soils, the radicle root may not emerge until one to two weeks after planting (Nielsen, 2010b).
The coleoptile emerges next from the embryo side of the kernel within one to many days of the appearance of the radicle, depending on soil temperature. The coleoptile raise is due of the elongation of the mesocotyl. The coleoptile is a rigid piece of plant tissue that completely encloses the four to five embryonic leaves (plumule) that formed during grain development of the seed production year. The plumule leaves slowly enlarge and eventually cause the coleoptile to split open as it nears the soil surface (Ritchie et al, 1993).

The seminal roots emerge next and initially elongate towards the dent end of the kernel. The first set of so-called "permanent" roots begins elongating from the first node at the crown of the seedling at approximately the V1 leaf stage (1 leaf with visible leaf collar) and is clearly visible by V2 (Carter et al, 2009).

The amount of corn root depends on how they perform genotypes on production capacity, 
resistance to drought, but also root lodging (Căbulea, 1983; Gruia, 1986). The coleoptile and mesocotyl length of maize plantlets are important for the depth at which specific genotypes are sowing. These elements, combined with starch endosperm reserve and response to oscillating temperatures are responsible for uniformity and further development of plants (Nielsen, 2010b).

Taking into account the importance of root and coleoptile and mesocotyl length of maize young plants was considered appropriate to analyse the variability of these traits in a set of maize local populations. The best populations will be used as genitors for obtaining inbreed lines. The choice for local populations is sustained by the fact that they were formed on different types of soil, under different climatic conditions and with different sowing technologies (the sowing depth ranged between $2-4 \mathrm{~cm}$ and $12-15 \mathrm{~cm}$ )

\section{MATERIALS AND METHODS}

Root system development, the mesocotyl and the coleoptile were studied in a number of 41 local populations at The Maize Breeding Department of
ARDS Turda, in 2013. For each local population, 10 plantlets were analysed for the traits previously mentioned (Table 1).

\section{RESULTS AND DISCUTIONS}

The length of the embrionary root, for the 41 local populations included in this study, ranged between $25.50 \mathrm{~cm}$ and $30.52 \mathrm{~cm}$, with an average value of $28.42 \mathrm{~cm}$. The variability coefficient and the variance were low, which proves the low variability of this feature within the experimental lot. The average length of primary roots was 17.37 $\mathrm{cm}$, inferior to the average value for embrionary roots. On the other hand, the variance was much higher than it was for embrionary roots. The variability coefficient shows a medium variability of this character. The average number of primary roots, for the 41 local populations ranged between 2.40 and 6.70 , with an average value of 4.34 . The amplitude for the number of primary roots is quite high. The variance was also high, as well as the variability coefficient, indicating a high variability for this trait (Table 2).

Tab. 1. Corn local population studied at ARDS Turda in 2013

\begin{tabular}{lccc}
\hline Lapusneac & Biertan & Mara 5 & Tulghes (B160-84) \\
\hline Galben timpuriu & Brosteni 13 & Magura Ilvei & Valea Seaca \\
\hline Ardusat Caltina & Drambar & Molid 11 & Vata de Jos \\
\hline Coldau & Desesti 2 & Orasul Nou & Valea Draganului \\
\hline Crairat & Eremitu & Paucesti & Vatra Moldovitei \\
\hline Campulung 267 & Frumosu 32 & Satul Lung & Zetea B145-84 \\
\hline Ciocanesti & Firiza 2 & Sacel 9 & Boldut 13 \\
\hline Corbu B 188-84 & Lancram & Straja 18 & Mihaiesti CN3S \\
\hline Botiza 1 & Tuncanii de Sus & Telciu & Turda - 1 CJ \\
\hline Bogdan Voda & Ilva Mare & Tulca & \\
\hline
\end{tabular}

Tab. 2 The variability study of the root's characters of maize local populations, ARDS Turda 2013

\begin{tabular}{lccc}
\hline \multirow{2}{*}{ Statistical parameter } & \multicolumn{3}{c}{ Statistical analysis } \\
\cline { 2 - 4 } & Embrionary roots length cm & Primary roots length cm & Primary roots number \\
\hline Mean & 28.42 & 17.37 & 4.34 \\
\hline Standard error & 0.18 & 0.37 & 0.15 \\
\hline Standard deviation & 1.20 & 2.41 & 1.02 \\
\hline Variance & 1.44 & 5.84 & 1.04 \\
\hline Variability coefficient & 4.23 & 13.92 & 23.53 \\
\hline Range & 5.02 & 12.56 & 4.33 \\
\hline Minimum & 25.50 & 10.30 & 2.40 \\
\hline Maximum & 30.52 & 22.90 & 6.70 \\
\hline Count & 41 & 41 & 41 \\
\hline Confidence level 95\% & 0.37 & 0.76 & 0.32 \\
\hline
\end{tabular}


The length of the mesocotyl, ranged between $1.12 \mathrm{~cm}$ and $1.90 \mathrm{~cm}$, with an average value of $1.43 \mathrm{~cm}$. The variability coefficient proves medium variability of this trait. The average length of coleoptile was $3.50 \mathrm{~cm}$, superior to the average length of mesocotyl. The variability of this character was low. The average plantlet length, for the 41 local populations ranged between 4.06 and 6.10 , with an average value of 4.92 . The variability coefficient indicates a low variability for this trait (Table 3 ).

Tables 4 and 5 present the populations with the highest/lowest values of the length of the embrionary roots, primary roots, mesocotyl, coleoptile and plantlets in the maize populations ranking the first five and the last five positions within the experimental lot.
The length of the embrionary roots of the first five ranking populations had values between 30.52 (Ardusat Caltina) and $29.46 \mathrm{~cm}$ (Orasul Nou), as compared to the average value of 28.42 $\mathrm{cm}$. The local populations ranking last, within the lot of 41, had values between 26.72 (Mihaiesti CN3S) and $25.50 \mathrm{~cm}$ (Sacel 9). We noticed that all the populations with low values of the length of the embrionary root come from colder regions (Table 4).

The populations ranking high in the top of the longest embrionary roots also had relatively high values of the average length of primary roots, except for the local populations coming from Ciocanesti and Eremitu. All local populations with low values of the length of the embrionary roots

Tab. 3. The variability study of the mesocotyl, coleoptile and plantlet length of maize local populations, ARDS Turda 2013

\begin{tabular}{lccc}
\hline \multirow{2}{*}{ Statistical parameter } & \multicolumn{3}{c}{ Statistical analysis } \\
\cline { 2 - 4 } & Mesocotyl length $\mathrm{cm}$ & Coleoptile length $\mathrm{cm}$ & Plantlet length $\mathrm{cm}$ \\
\hline Mean & 1.43 & 3.50 & 4.92 \\
\hline Standard error & 0.03 & 0.05 & 0.07 \\
\hline Standard deviation & 0.19 & 0.34 & 0.47 \\
\hline Variance & 0.03 & 0.11 & 0.22 \\
\hline Variability coefficient & 13.74 & 9.81 & 9.67 \\
\hline Range & 0.78 & 1.38 & 2.00 \\
\hline Minimum & 1.12 & 2.78 & 4.06 \\
\hline Maximum & 1.90 & 4.20 & 6.10 \\
\hline Count & 41 & 41 & 41 \\
\hline Confidence level 95\% & 0.06 & 0.10 & 0.15 \\
\hline
\end{tabular}

Tab. 4. The local population with longest/shortest embrionary and primary roots

\begin{tabular}{clccc}
\hline Classification & Local population & $\begin{array}{c}\text { Embrionary roots' } \\
\text { length cm } \\
\text { 9 days after } \\
\text { germination }\end{array}$ & Local population & $\begin{array}{c}\text { Primary roots' } \\
\text { length cm } \\
\text { 9 days after } \\
\text { germination }\end{array}$ \\
\hline 1 & Ardusat Caltina & 30.52 & Lapusneac & 22.86 \\
\hline 2 & Ciocanesti & 30.22 & Satu Lung & 21.97 \\
\hline 3 & Eremitu & 29.86 & Vata de Jos & 21.30 \\
\hline 4 & Valea Seaca & 29.84 & Orasul Nou & 19.74 \\
\hline 5 & Orasul Nou & 29.46 & Desesti 2 & 19.59 \\
\hline $\mathrm{X}$ & Average & 28.42 & Average & 17.37 \\
\hline 37 & Mihaiesti CN3S & 26.72 & Campulung 267 & 15.40 \\
\hline 38 & Campulung 267 & 26.52 & Straja 18 & 13.66 \\
\hline 39 & Straja 18 & 26.39 & Telciu - 1 & 13.13 \\
\hline 40 & Molid & 25.68 & Mihaiesti CN3S & 12.98 \\
\hline 41 & Sacel 9 & 25.50 & Galben timpuriu & 10.30 \\
\hline Confidence interval 95\% & 0.3793 & & 0.76 \\
\hline
\end{tabular}


Tab. 5. The local population with highest/lowest mesocotyl, coleoptile and plantlet length

\begin{tabular}{clccccc}
\hline $\begin{array}{c}\text { Classifi- } \\
\text { cation }\end{array}$ & Local population & $\begin{array}{c}\text { Mesocotyl } \\
\text { length cm } \\
9 \text { days after } \\
\text { germination }\end{array}$ & $\begin{array}{c}\text { Local } \\
\text { population }\end{array}$ & $\begin{array}{c}\text { Coleoptile } \\
\text { length cm } \\
9 \text { days after } \\
\text { germination }\end{array}$ & $\begin{array}{c}\text { Local } \\
\text { population }\end{array}$ & $\begin{array}{c}\text { Plantlet } \\
\text { length cm } \\
\text { days after } \\
\text { germination }\end{array}$ \\
\hline 1 & Tulca & 1.90 & Tulca & 4.16 & Tulca & 6.06 \\
\hline 2 & Ciocanesti & 1.78 & Lapusneac & 4.11 & Lapusneac & 5.74 \\
\hline 3 & Mihaiesti CN3S & 1.75 & Paucesti & 4.11 & Drambar & 5.63 \\
\hline 4 & Drambar & 1.73 & Sacel 9 & 4.07 & Orasul Nou & 5.53 \\
\hline 5 & Orasul Nou & 1.71 & Biertan & 4.05 & Biertan & 5.50 \\
\hline X & Average & 1.43 & Average & 3.50 & Average & 4.92 \\
\hline 37 & Ilva Mare & 1.19 & Ilva Mare & 3.17 & Ilva Mare & 4.36 \\
\hline 38 & Botiza 1 & 1.18 & Vatra & 3.11 & Vatra & 4.24 \\
\hline 39 & Turda 1 Cj & 1.18 & Soldovitei & Moldovitei & 4.18 \\
\hline 40 & Corbu B 188-84 & 1.13 & Botiza 1 & 2.91 & Molid 11 & 4.88 \\
\hline 41 & Vatra Moldovitei & 1.12 & Molid 11 & 2.78 & Satul Lung & 4.11 \\
\hline Confidence interval 95\% & 0.06 & & 0.10 & & 4.06 \\
\hline
\end{tabular}

also had low values for the length of the primary roots (Table 4).

It is, in a way, surprising to have the Galben Timpuriu cultivar ranking last in what regards the average length of the primary roots, considering the fact that the length of the embrionary root in this cultivar is higher than the mean value of the experimental system. In this cultivar, the number of primary roots was also the lowest in the whole lot of 41 local populations (Table 4 and 5).

The first ranking populations had high values, over the mean, for the length of the mesocotyl, the only exceptions being the populations from Eremitu and Valea Seaca; for the same populations, the length of the coleoptile was also lower than the mean value of the 41 populations. Similar aspects have been noticed in what regards the length of the plantlet in the two local populations (Table 4 and 5).

The mean value of the set of 41 populations in what regards the length of the mesocotyl was $1.43 \mathrm{~cm}$, with values ranging between $1.12 \mathrm{~cm}$ (Vatra Moldovitei) and $1.90 \mathrm{~cm}$ (Tulca-Bihor). The local populations ranking last, within the lot of 41, had values between 1.12 (Vatra Moldovitei) and $1.19 \mathrm{~cm}$ (Ilva Mare). Populations with the lowest mesocotyl length are originated from mountain area, excepting population Turda $1 \mathrm{Cj}$ (Table 5).

Comparing the local populations for length of mesocotyl and length of roots, coleoptile and plantlet, no correlation was noticed between mesocotyl and primary roots length. Between length of mesocotyl and coleoptile and plantlet there was a correlation, which is a positive aspect for breeding programmes.

The highest value for coleoptile length was recorded in Tulca, Lapusneac, Paucesti and Biertan; all of these populations are collected from plain areas. The populations with the lowest values of this trait, Molid 11, Botiza 1, Satul Lung, Vatra Moldovitei and Ilva Mare are originated from mountain areas. The average value fo this traits was 3.50, higher in comparison with the average value for the length of mesocotyl. There were no correlations between coleoptile length and root length.

The average of plantlet length was 4.92. The local population of Tulca had the highest value for this trait, while Botiza 1 provided the lowest one. The lowest values for this trait were recorded in local populations from mountain areas (Table 5).

\section{CONCLUSION}

There is insufficient phenotypic and genetic variability for studied traits in maize local populations so that it cannot be exploited in breeding programmes. The variability was low for embrionary root, coleoptile and plantlet length and medium for primary roots and mesocotyl length. 
Between length of mesocotyl and length of coleoptile and plantlet there was a correlation, which is a useful aspect for simultaneous selection in breeding programmes.

The size of roots, mesocotyl and coleoptile is influenced by area were local population is formed. Local population from mountain areas show low values for traits studied.

Local populations with high root and coleoptile length such as Tulca, Lapusneac and Biertan can be used for obtaining some inbred lines of maize resistant to lodging and to drought in the early growing season.

\section{REFERENCES}

1. Carter P, Nafziger E, Lauer J (2009). Uneven Emergence in Corn. North Central Regional Extension Pub. No. 344. Available at http://corn.agronomy.wisc.edu /Pubs/ UWEX/NCR344.pdf [URL accessed September 2014].
2. Căbulea I (1983). Unele aspecte statistice ale analizei genetice şi a capacităii de producție. Probleme legate de genetică teoretică și aplicată. vol XV. 31-50.

3. Gruia F (1986). Cultura porumbului. Centrul de material didactic şi propagandă agricolă. Bucureşti. 8-40.

4. Nielsen RL (2010a). Root development in young corn. Purdue Univ. dept. of Agronomy Corny News Network. http://www.kingcorn.org/news/timeless/Roots.html [URL accessed September 2014]

5. Nielsen RL (2010b). Requirements for Uniform Germination and Emergence of Corn. Corny News Network, Purdue Univ. [On-Line]. Available at http:// www.kingcorn.org /news/timeless/GermEmergReq. html. [URL accessed September 2014].

6. Nielsen, RL (2010c). The Emergence Process in Corn. Corny News Network, Purdue Univ. [On-Line]. Available at http://www.kingcorn.org/news/timeless/Emergence. html. [URL accessed September 2014].

7. Ritchie SW, Hanway JJ, Benson GO (1993). How a Corn Plant Develops (SP-48). Iowa State Univ. [On-Line]. Available at http://www.extension.iastate.edu/hancock/ info/corn.htm. [URL accessed September 2014]. 